\title{
SEASONAL PATTERNS OF PHENYLALANINE AMMONIA-LYASE ACTIVITY AND TOTAL PHENOL AND TANNIN CONTENTS IN Stryphnodendron adstringens (Mart.) Coville
}

\author{
AVALIAÇÃO SAZONAL DA ATIVIDADE DA FENILALANINA AMÔNIA-LIASE E DOS TEORES \\ DE FENÓIS E TANINOS TOTAIS EM Stryphnodendron adstringens (Mart.) Coville
}

\author{
Ana Hortência Fonsêca Castro ${ }^{1}$ Amauri Alves de Alvarenga ${ }^{2}$ João Paulo Rodrigues Alves Delfino \\ Barbosa $^{2}$ Thaís de Oliveira Fontes Mansur ${ }^{3}$ Ana Cardoso Clemente Filha Ferreira de Paula ${ }^{4}$
}

\begin{abstract}
There were performed analyses of the leaves and stem bark of Stryphnodendron adstringens, a Brazilian Cerrado plant, to examine the seasonal patterns of phenylalanine ammonia-lyase activity and total phenol and tannin contents in 16 adult individuals under field conditions. The measurements of gas exchange parameters, including net photosynthesis, transpiration and stomatal conductance, as well as the photosynthetic photon flux density, leaf temperature, vapor pressure deficit and leaf water potential were also performed. The results were subjected to a principal component analysis. The values obtained for stomatal conductance, net photosynthesis, transpiration, water use efficiency, minimum water potential and photosynthetic photon flux density were higher in the rainy season, while the maximum water potential and vapor pressure deficit in the atmosphere were similar between seasons. The seasonal variations in gas exchange characteristics were influenced by changing weather conditions and were positively correlated with higher air temperatures, rainfall amounts and relative air humidity and negatively correlated with increased insolation. There was no correlation between the maximum leaf water potential and any of the weather variables. Phenylalanine ammonia-lyase activity was similar in the dry and rainy seasons, and higher levels of total phenols and tannins were observed in the dry and rainy seasons, respectively. Phenylalanine ammonia-lyase activity and total phenol contents were negatively influenced by temperature and rainfall in the dry season, and the total tannin contents were mainly correlated with higher temperatures and a lower influence of rainfall in the rainy season.
\end{abstract}

Keywords: gas exchange; Cerrado; phenolic compounds; seasonality.

\section{RESUMO}

Folhas e cascas do caule de Stryphnodendron adstringens, uma espécie do Cerrado brasileiro, foram utilizadas para examinar os padrões sazonais da atividade da fenilalanina amônia-liase e os teores de fenóis e taninos totais em 16 indivíduos adultos, em condições de campo. Avaliações das trocas gasosas, incluindo fotossíntese líquida, transpiração, condutância estomática, densidade de fluxo de fótons fotossinteticamente ativos, temperatura da folha, deficit de pressão de vapor e potencial hídrico foliar foram realizadas. Os resultados foram submetidos à análise de componentes principais. A condutância estomática, fotossíntese

1 Farmacêutica-Bioquímica, Dra $^{\mathrm{a}}$., Professora Adjunta do Programa de Pós-Graduação em Ciências Farmacêuticas, Campus Centro-Oeste, Universidade Federal de São João Del-Rei, Rua Sebastião Gonçalves Coelho, 400, Chanadour, CEP 35501-296, Divinópolis (MG), Brasil. acastro@ufsj.edu.br

2 Engenheiro Agrônomo, Dr., Professor Titular do Programa de Pós-Graduação em Fisiologia Vegetal, Departamento de Biologia, Universidade Federal de Lavras, Aquenta Sol, CEP 37200-000, Lavras (MG), Brasil. amauriaa@dbi.ufla.br / jp.barbosa@dbi.ufla.br

3 Engenheira Florestal, Departamento de Biologia, Universidade Federal de Lavras, Aquenta Sol, CEP 37200-000, Lavras (MG), Brasil. thatytofm@gmail.com

4 Engenheira Agrônoma, Dra ${ }^{\mathrm{a}}$, Professora Adjunta do Curso de Agronomia, Campus Bambuí, Instituto Federal de Minas Gerais, Faz. Varginha - Rodovia Bambuí/Medeiros - km 05, Bambuí, CEP 38900-000, Bambuí (MG), Brasil.ana.paula@ifmg.edu.br 
líquida, transpiração, eficiência do uso da água, potencial hídrico mínimo e densidade de fluxo de fótons fotossinteticamente ativos foram maiores na estação chuvosa, enquanto que o potencial hídrico máximo e o deficit de pressão de vapor na atmosfera foram semelhantes entre as estações. As variações sazonais nas características de trocas gasosas foram influenciadas por mudanças nas condições climáticas e se correlacionaram positivamente com as maiores temperaturas, precipitação e umidade relativa do ar e negativamente com o aumento da insolação. Não houve correlação entre o potencial hídrico foliar máximo e as demais variáveis climáticas. A atividade da fenilalanina amônia-liase foi semelhante nas estações seca e chuvosa e os maiores teores de fenóis e taninos totais foram observados nas estações seca e chuvosa, respectivamente. A atividade da fenilalanina amônia-liase e os teores de fenóis totais foram influenciados negativamente pela temperatura e precipitação na estação seca, e os teores de taninos totais foram correlacionados principalmente com temperaturas mais elevadas, com menor influência da precipitação na estação chuvosa.

Palavras-chave: trocas gasosas; Cerrado; compostos fenólicos; sazonalidade.

\section{INTRODUCTION}

The Brazilian Cerrado represents the major savanna region in America and covered approximately 2 million $\mathrm{km}^{2}$ of Brazil's territory. This formation occurs under a tropical semi-humid climate with pronounced seasonality characterized by hot and wet summers, and cold and dry winters (BATLLE-BAYER; BATJES; BINDRABAN, 2010). The vegetation is constrained by multiple adverse factors, especially fire, low levels of nutrients in soil, high evapotranspiration rates and high insolation levels (HARIDASAN, 2008). Oh, Trick and Rajashekar (2009) reported that the availability of environmental resources is a key factor causing temporal fluctuations in metabolites levels.

The phenylpropanoid pathway constitutes a major secondary metabolic pathway in plants, leading to the synthesis of a variety of compounds, such as flavonoids, anthocyanins, tannins, plant hormones, lignins and benzoic acid derivatives (WINKEL-SHIRLEY, 2001). Phenylpropanoids are derived from trans-cinnamic acid, a deamination product of L-phenylalanine through a reaction catalyzed by the enzyme L-phenylalanine ammonia-lyase (PAL; EC 4.3.1.5) (SREELAKSHMI; SHARMA, 2008). PAL activity increases, and many phenylpropanoids accumulate as a consequence of biotic factors, such as herbivorous insects and infection by viruses, bacteria and fungi, and various abiotic stressors, as drought, heat, UV-B light, low and high temperatures, wounding and low nitrogen (BARBEHENN et al., 2009; OH; TRICK; RAJASHEKAR, 2009; GERM et al., 2010; GIBERT et al., 2012).

Tannins are polyphenolic compounds considered C-based secondary metabolites (HEYWORTH et al., 1998). The concentration of tannins is a highly plastic trait; it varies with plant genotype, tissue developmental stages and environmental conditions (BARBEHENN; CONSTABEL, 2011). The tannins (20-30\%) in the stem bark of Stryphnodendron adstringens (Mart.) Coville, a typical species of the Brazilian Cerrado are associated with the therapeutic use of this plant in folk medicine as an anti-inflammatory agent (COSTA et al., 2010), wound healing (HERNANDES et al., 2010), for the protection of gastric mucous membranes (FALCÃO et al., 2008) and antiprotozoan (ALBERNAZ et al., 2010).

Although there is a great deal of knowledge regarding the environmental constraints on plant development and growth in the Cerrado, the physiological and biochemical basis of the responses of plants to the variations of the physical environment are poorly understood. Thus, three main questions were addressed in our study: (1) How do seasonal patterns of environmental variations affect gas exchange and water relations in Stryphnodendron adstringens? (2) How do environmental constraints affect PAL activity and phenol and tannin contents? (3) How are the gas exchanges and water relations connected to PAL activity as well as phenol and tannin contents, and what are the environmental influences on those links? 


\section{MATERIAL AND METHODS}

\section{Site description and plant material}

The study was carried out in a remnant of Cerrado sensu stricto (24 ha) in the municipality of

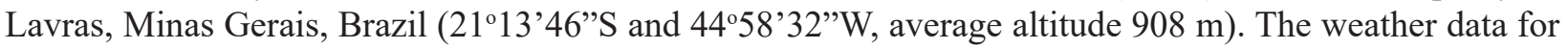
the years 2002-2003 were provided by Lavras' Main Meteorological Station. The study area is characterized by a mesothermic climate (type Cwa - moist temperate) (KÖPPEN, 1948), with two distinct seasons: a dry season from April to September and a rainy season from October to March. The annual average temperature is $19.4{ }^{\circ} \mathrm{C}$, with the lowest temperatures occurring during the driest months of the year. The average annual rainfall and relative humidity are 1,529.7 $\mathrm{mm}$ and 76.2\%, respectively (BRASIL, 1992). Sixteen adult individuals of Stryphnodendron adstringens (Mart.) Coville (Fabaceae - Papilionoideae) $(4.20 \pm 0.19 \mathrm{~m}$ in height) were assessed randomly during fourteen months, from October 2002 to late November 2003. The exsiccates (n. 17227) were deposited in the ESAL Herbarium of the Federal University of Lavras, Minas Gerais, Brazil.

\section{Leaf gas exchange}

Measurements of net photosynthesis (A), transpiration rate (E), stomatal conductance (gs), photosynthetic photon flux density (PPFD), leaf temperature (LT), water use efficiency (WUE) and vapor pressure deficit (VPD) were performed using an infrared gas analysis system (IRGA - ADC-LCA-4, Hoddesdon, UK). Two fully expanded, mature leaves per individual were sampled on clear sky days, always from 10:00 am to midday.

\section{Leaf water potential}

The maximum (6:00 a.m.) and minimum (midday) leaf water potentials (WPmax and WPmin) were evaluated under the same conditions as gas exchange using a Scholander-type pressure chamber (Soil Moisture 3005 model).

\section{PAL activity}

PAL activity was assayed using the method described by Assis et al. (2001), in a reaction medium containing $0.1 \mathrm{M}$ borate buffer, $\mathrm{pH}$ 8.8, $30 \mathrm{mM} \mathrm{L}$-phenylalanine, and an aliquot of the leaf extract containing the enzyme in a total volume of $3 \mathrm{~mL}$. PAL activity was determined based on the production of cinnamate for $90 \mathrm{~min}$ at $30^{\circ} \mathrm{C}$ under continuous shaking, and measured as the change in absorbance at $290 \mathrm{~nm}$ (ZUCKER, 1965). The enzyme activity was expressed in $\mu$ mol cinnamic acid h $\mathrm{h}^{-1} \mathrm{~g}^{-1}$ of fresh mass.

\section{Total phenol and tannin contents}

Fragments of stem bark (500 mg) were lyophilized, crushed and subjected to extraction with methanol: water $(1: 1 \mathrm{v} / \mathrm{v})$ under reflux. The final volume of the extract was $25 \mathrm{~mL}$, and an aliquot of 100 $\mu \mathrm{L}$ was used to determine the total phenol content spectrophotometrically using Folin-Ciocalteu's reagent, as described by Singleton and Rossi (1965) and Pastrana-Bonilla et al. (2003). The total tannins were determined according to the Radial Diffusion method, described by Hagerman (1987).

\section{Statistical analysis}

The data on meteorological, gas exchange and biochemical variables were subjected to ShapiroWilk test and Bartlett $\left(\chi^{2}\right)$ tests to check the normality and homogeneity of variances, respectively. All variables were normally distributed and the variances were homogeneous across months. Thus, principal 
components analysis (PCA) and Pearson's correlation analysis were carried out to climatic, gas exchange and biochemical variables, considering the months as cases. When the variables were grouped by season, they were not normally distributed. Under these conditions, comparisons between seasons were performed using the Mann-Whitney test $(\mathrm{p}<0.01)$. All data analyses were performed using the statistical program $\mathrm{R}(\mathrm{R}$ DEVELOPMENT CORE TEAM, 2011).

\section{RESULTS AND DISCUSSION}

The climatological characteristics of the experimental period were considered atypical compared to normal climatic conditions verified from 1960 to 1990, which may be related to the observed changes in the typical seasonality of the study region (Figure 1). In general, the experimental period was warmer and drier than expected for the region. The maximum, mean and minimum air temperatures were, on average,

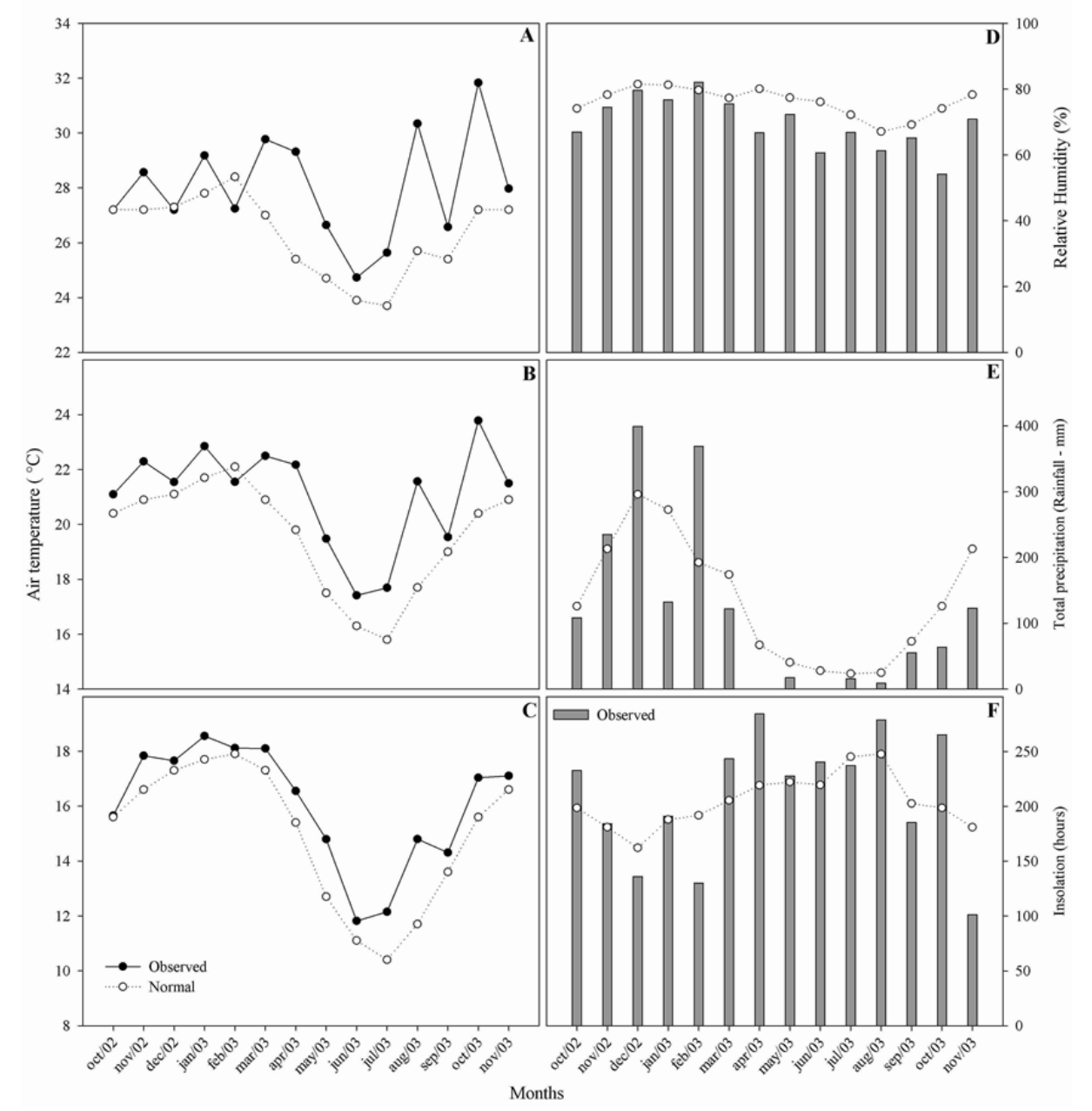

FIGURE 1: Values of the average monthly maximum (A), medium (B) and minimum air temperatures (C), relative air humidity (D), monthly total rainfall (E) and insolation (F), observed from October 2002 to November 2003. The solid line with filled circles and dark bars represents the observed values, and the dotted line with unfilled circles represents normal values (1961-1990).

FIGURA 1: Valores médios mensais das temperaturas do ar máxima (A), média (B) e mínima (C), umidade relativa do ar (D), precipitação mensal total (E) e insolação (F) observadas de outubro de 2002 a novembro de 2003. A linha contínua com círculos cheios e as barras escuras representam os valores observados, e as linhas pontilhadas com círculos vazios representam valores normais (1961-1990). 
$1.7{ }^{\circ} \mathrm{C}, 1.4{ }^{\circ} \mathrm{C}$ and $1.1{ }^{\circ} \mathrm{C}$ above normal values, respectively, with the months of August and October 2003 presenting the largest discrepancies of expected values and being warmer (Figures 1A, 1B and 1C). However, the reduction of the rainfall by $218 \mathrm{~mm}$ and an increase in isolation of 75 hours were observed (Figures $1 \mathrm{E}$ and $1 \mathrm{~F}$ ). There were no major shifts in relative humidity, which was reduced by approximately $7 \%$ in relation to normal values.

The PCA showed differences in weather conditions between months in the experimental period (Figure 2). These differences were evident along the first principal component and the second component, which explained $58.0 \%$ and $39.0 \%$ of the variance, respectively. The rainfall, minimum temperature and insolation were the variables with higher contribution to the first component and the maximum and medium temperatures along with the relative air humidity mostly contributed to the second component. The first component separated the study months in two groups: dry season (April to September/2003) and rainy

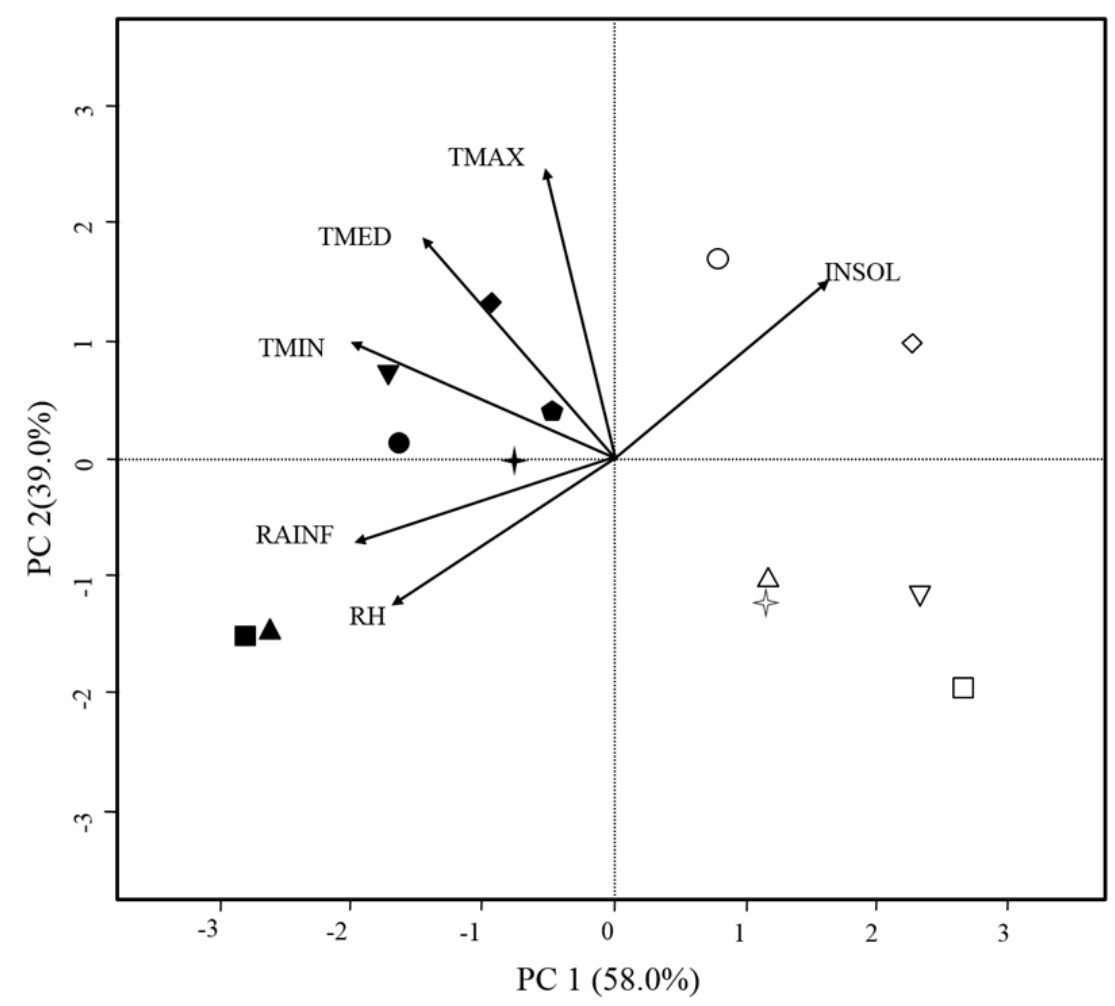

FIGURE 2: Biplot of climatic variables during the experimental period: dark circle (Nov./2002); dark triangle (Dec./2002); dark inverted triangle (Jan/2003); dark square (Feb./2003), dark diamond (Mar./2003); light circle (Apr./2003); light triangle (May/2003); light inverted triangle (June/2003); light square (July/2003); light diamond (Aug./2003); light star (Sept./2003); dark pentagon (Oct./2003); dark star (Nov./2003). The vectors represent the behavior of insolation (INSOL), relative air humidity (RH), rainfall (RAINF) and the maximum (TMAX), medium (TMED) and minimum (TMIN) air temperatures.

FIGURA 2: Gráficos sobrepostos das variáveis climáticas durante o período experimental: círculo escuro (Nov/2002), triângulo escuro (Dez/2002), triângulo escuro invertido (Jan/2003), quadrado escuro (Fev/2003); diamante escuro (Mar/2003), círculo claro (Abr/2003), triângulo claro (Mai/2003), triângulo claro invertido (Jun/2003), quadrado claro (Jul/2003), diamante claro (Ago/2003), estrela clara (Set/2003), pentágono escuro (Out/2003), estrela escura (Nov/2003). Os vetores representam o comportamento da insolação (INSOL), umidade relativa do ar $(\mathrm{RH})$, precipitação (RAINF) e a temperatura do ar máxima (TMAX), média (TMED) e mínima (TMIN). 
season (October/2002 to March/2003 and October and November/2003), agreeing with the seasonality reports by Dantas, Carvalho and Ferreira (2007). In general, the months characterized as part of the rainy season displayed higher levels of rainfall, temperature and relative humidity and lower isolation compared to the months of the dry season.

The gas exchange and physiological characteristics were analyzed and grouped after PCA in relation to the months corresponding to the dry and rainy seasons. The gas exchange characteristics and leaf water potential values are shown in Figure 3. In general, the variables stomatal conductance, net photosynthesis, transpiration, water use efficiency, minimum leaf water potential and photosynthetic active radiation

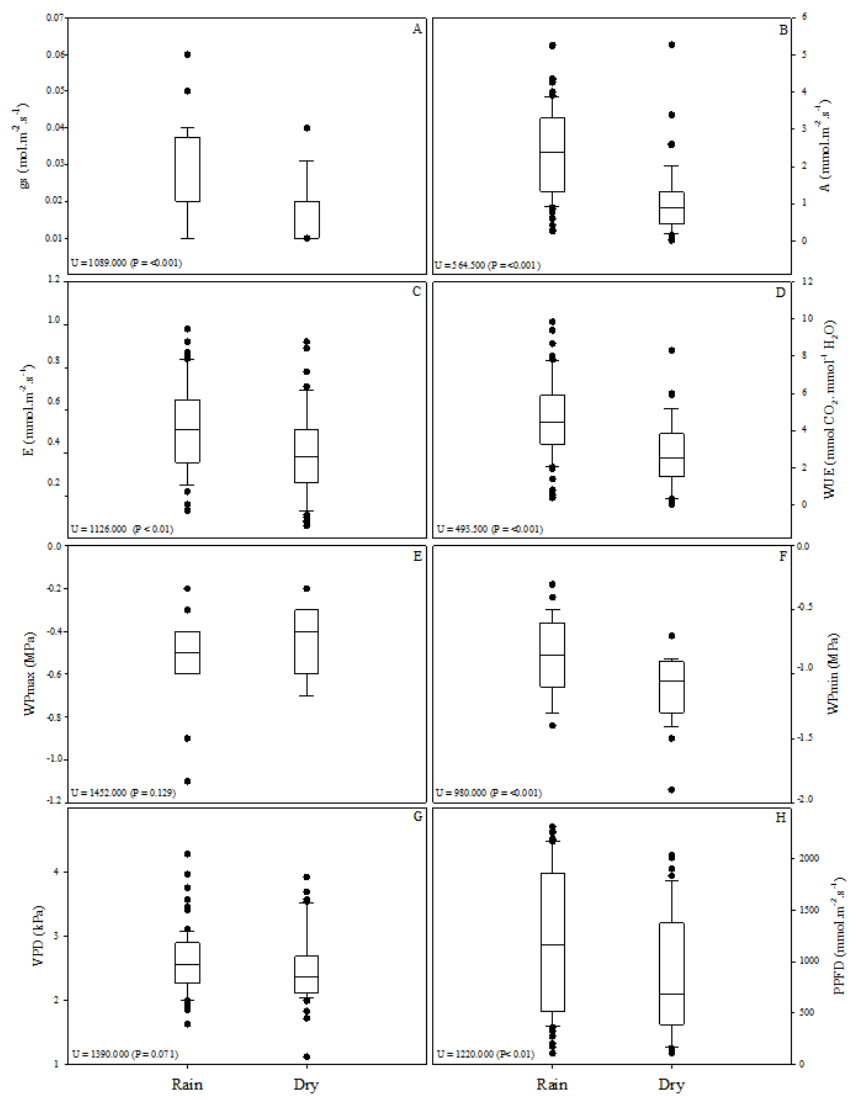

FIGURE 3: Box-plots representing the values for gas exchange characteristics in the rainy and dry seasons. The bars represent values between 25 and $75 \%$, while the solid lines represent the median, and the whiskers represent values between 5 and $95 \%$ of the data distribution. The circles represent outlier values. A- stomatal conductance (gs), B- net photosynthesis (A), C- transpiration rate (E), D- water use efficiency (WUE), E- maximum leaf water potential (WPmax), F- minimum leaf water potential (WPmin), G- Vapor pressure deficit in the atmosphere (VPD); $\mathrm{H}$ - Photosynthetic photon flux density (PPFD). The values obtained from the Mann-Whitney test $(\mathrm{U}, \mathrm{P}<0.01)$ are shown in the lower left corner of each plot.

FIGURA 3: Gráficos em caixa representando os valores para as características de trocas gasosas nas estações chuvosa e seca. As barras representam valores entre 25 e $75 \%$, enquanto que as linhas sólidas menores dentro das barras representam a mediana, e as linhas sólidas que se projetam para fora das barras representam valores entre 5 e $95 \%$ da distribuição dos dados. Os círculos representam valores discrepantes. A - condutância estomática (gs), B - fotossíntese líquida (A), C - transpiração (E), D - eficiência no uso da água (WUE), E - potencial hídrico foliar máximo (WPmax), F - potencial hídrico foliar mínimo (WPmin), G - deficit de pressão de vapor (VPD), $\mathrm{H}$ - fluxo de fótons fotossinteticamente ativos (PPFD). Os valores obtidos a partir do teste de Mann-Whitney $(\mathrm{U}, \mathrm{P}<0,01)$ são mostrados na lateral esquerda inferior de cada gráfico. 
(Figures 3A-D, $\mathrm{F}$ and $\mathrm{H}$ ) were higher in the rainy season, while those for the maximum leaf water potential (Figure 3E) and vapor pressure deficit (Figure 3G) in the atmosphere were similar between seasons.

The seasonal patterns observed in gas exchange characteristics were greatly influenced by changing environmental conditions (Table 1). In general, gas exchange was positively correlated with increments in temperature, rainfall and relative humidity and negatively correlated with increased insolation. There was no correlation detected between the maximum leaf water potential and the environmental variables. In the rainy season, the increased rainfall, temperature and relative humidity and reduced insolation can be related to the highest photosynthetic capacity and water use efficiency in Stryphnodendron adstringens (Figures 1 and 3) According to Grace et al. (2006), strong seasonal variations in rainfall induce large seasonal fluctuations in energy, water and carbon fluxes in the Cerrado. The maximum net $C$ uptake is observed in the rainy season, when the system acts as a strong carbon sink, while during the dry season, biological activity decreases, and carbon flows occur (LILIENFEIN et al., 2001). The absence of correlations to the maximum seasonal leaf water potential may be associated with the characteristics of the study species, which exhibits a deep root system and, thus, displays a great capacity to recover its water status during the night (HARIDASAN, 2008). Deciduous and brevideciduous Cerrado tree species that hydraulically lift water tend to present conspicuously dimorphic root systems (SCHOLZ et al., 2007), which has profound implications for the regulation of the tree water balance as well as processes related to hydrological cycles in Cerrado ecosystems (BUCCI et al., 2008). According to Meinzer et al. (1999), variations in the plant water status of deeply rooted trees and shrubs are relatively small and that their maximum transpiration rates are not severely limited by seasonal variation in soil moisture.

TABLE 1: Pearson's correlation coefficients between gas exchange and water potential values with meteorological variables.

TABELA 1: Coeficiente de correlação de Pearson entre os valores das trocas gasosas e potencial hídrico com as variáveis meteorológicas.

Correlation of gas exchange and water potential with weather conditions

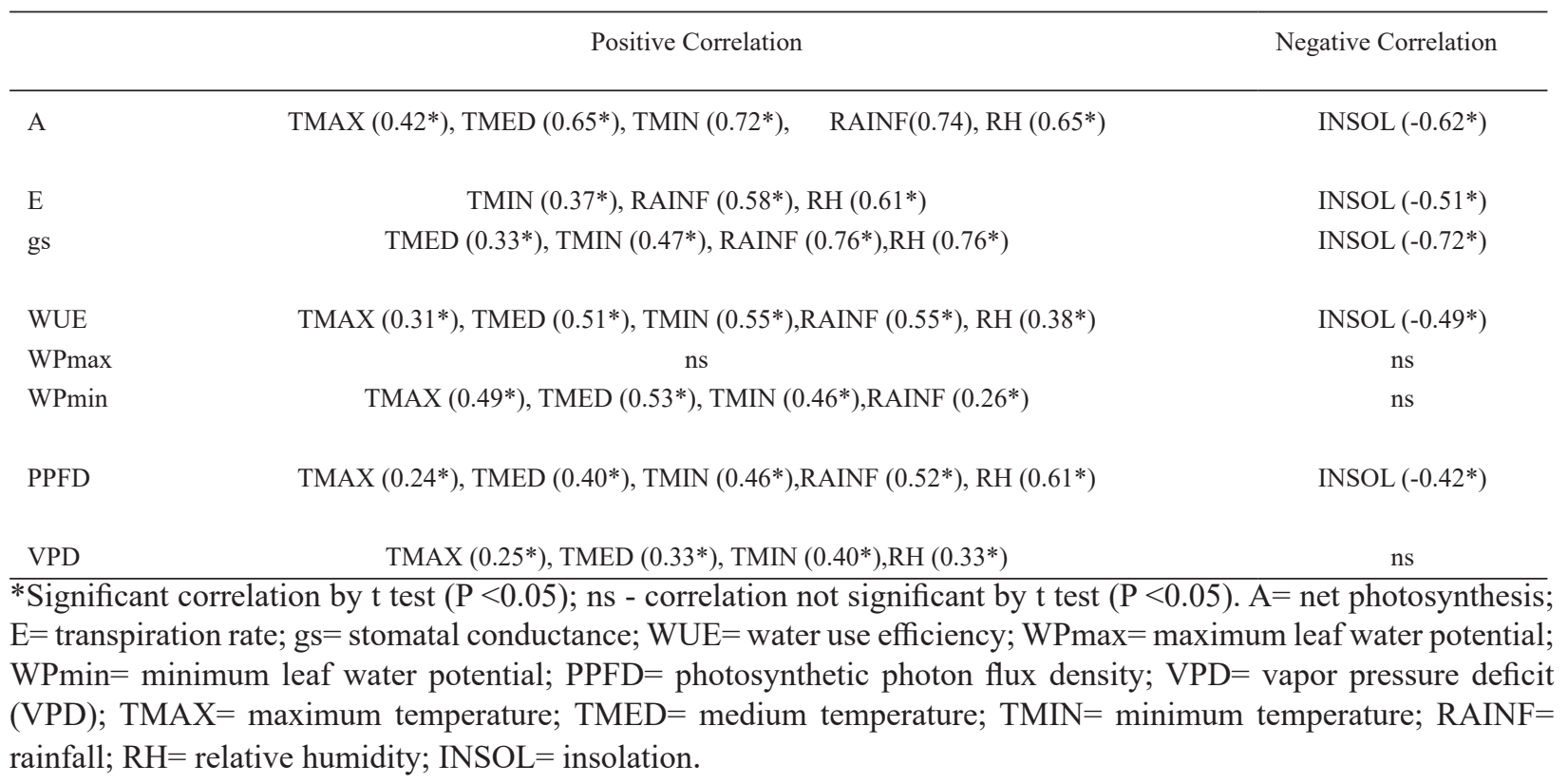


Concerning the biochemical variables (Figure 4) PAL activity was similar between seasons. Higher levels of total phenols and tannins were observed in the dry and rainy seasons, respectively. The Figure 5 and Table 2 show that in general, the PAL activity and total phenol contents were negatively influenced by temperature and rainfall in the dry season. The levels of total tannins showed an inverse behavior, mainly related to higher temperatures and a lower influence of rainfall in the rainy season (Figure 5A and Table 2). However, the relationship between these variables and rainfall should be viewed with caution, since there is a clear gap in the temporal physiological response patterns associated with the reduction of rainfall. According to Bucci et al. (2008), water availability in the soil may be more important than the amount of precipitated water in causing physiological effects in plants.

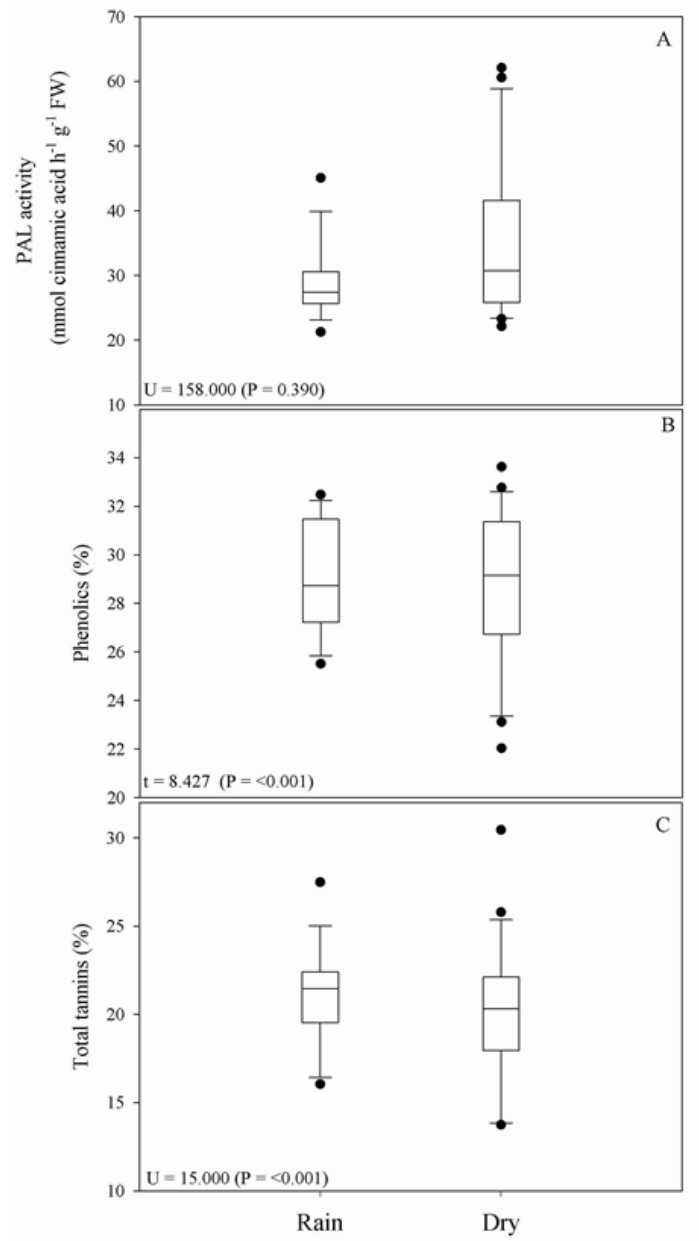

FIGURE 4: Box-plots representing the distribution values of biochemical variables obtained in the dry and in the rainy seasons. The bars represent values between 25 and $75 \%$, while the solid line represents the median, and the whiskers represent values between 5 and $95 \%$ of the data distribution. The circles represent outlier values. A- PAL activity, B- Total phenolics, C- Total tannins. The values from the Mann-Whitney $(\mathrm{U}, \mathrm{P}<0.01)$ or $\mathrm{t}$ test $(\mathrm{t}, \mathrm{P}<0.01)$ are shown in the lower left corner of each plot.

FIGURA 4: Gráficos em caixa representando a distribuição dos valores das variáveis bioquímicas obtidas nas estações seca e chuvosa. As barras representam valores entre 25 e $75 \%$, enquanto que as linhas sólidas menores dentro das barras representam a mediana, e as linhas sólidas que se projetam para fora das barras representam valores entre 5 e $95 \%$ da distribuição dos dados. Os círculos representam valores discrepantes. A - Atividade da fenilalanina amônia-liase; B - Fenóis totais. C - Taninos totais. Os valores obtidos a partir do teste de Mann-Whitney $(\mathrm{U}, \mathrm{P}<0,01)$ ou teste de $\mathrm{t}(\mathrm{t}, \mathrm{P}<0,01)$ são mostrados na lateral inferior esquerda de cada gráfico. 

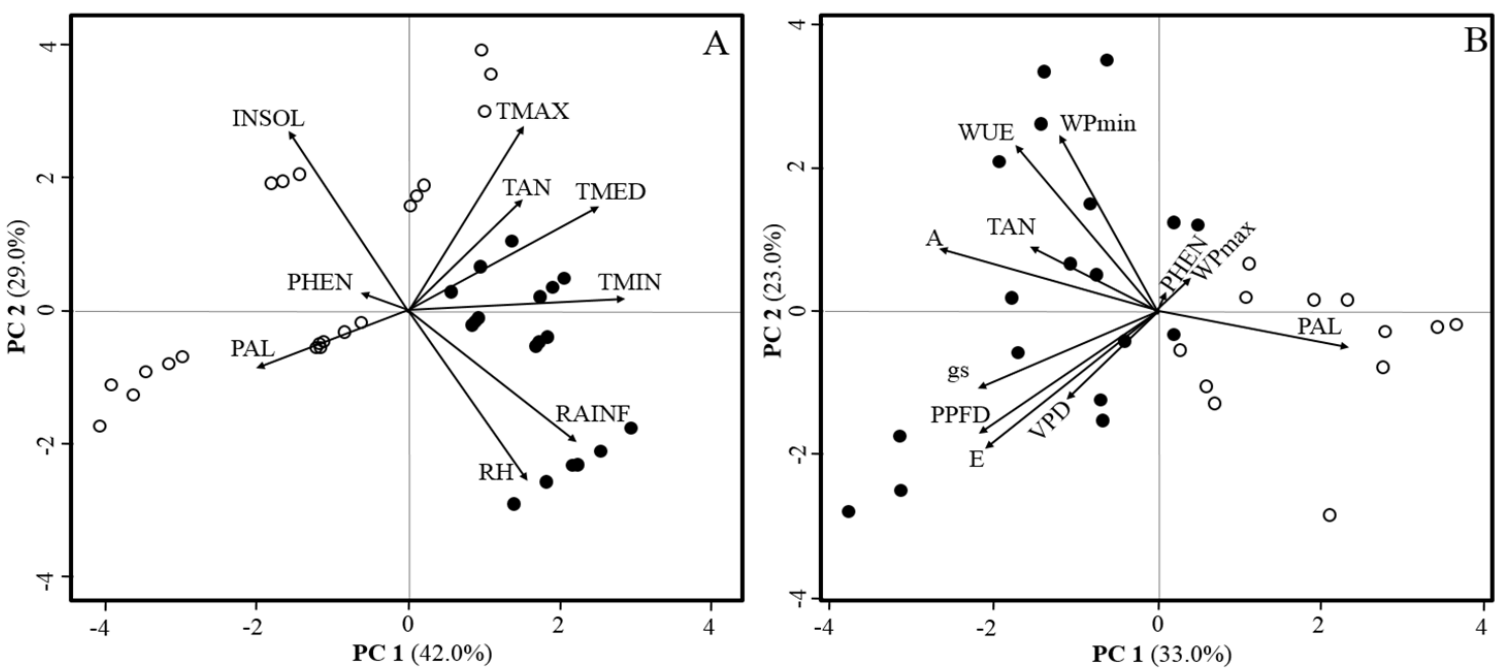

FIGURE 5: A- PCA biplot considering the environmental and biochemical variables in the dry and rainy seasons. B- PCA biplot considering the gas exchange and biochemical characteristics in the dry and rainy seasons. Photosynthetic photon flux density (PPFD), vapor pressure deficit (VPD), stomatal conductance (gs), net photosynthesis (A), transpiration rate (E), water use efficiency (WUE), maximum (WPmax) and minimum (WPmin) leaf water potential, maximum (TMAX), mean (TMED) and minimum (TMIN) air temperature, insolation (INSOL), rainfall (RAINF), relative air humidity (RH), PAL activity (PAL) and total phenol (PHEN) and tannin (TAN) contents. Dark circles represent the rainy season and light circles the dry season.

FIGURA 5: A - Gráficos sobrepostos da PCA considerando as variáveis ambientais e bioquímicas nas estações seca e chuvosa. B - Gráficos sobrepostos da PCA considerando as características de trocas gasosas e bioquímicas nas estações seca e chuvosa. Densidade de fluxo de fótons fotossinteticamente ativos (PPFD), deficit de pressão de vapor (VPD), condutância estomática (GS), fotossíntese líquida (A), transpiração (E), eficiência no uso da água (WUE), potencial hídrico foliar máximo (Wpmax) e mínimo (WPmin), temperatura do ar máxima (TMAX), média (TMED) e mínima (TMIN), insolação (INSOL), precipitação (RAINF), umidade relativa do ar (RH), atividade da PAL (PAL) e teores de fenóis (PHEN) e taninos (TAN) totais. Círculos escuros representam estação chuvosa e círculos claros representam estação seca.

According to Solecka and Kacperska (2003), phenolic compounds accumulate in the tissues affected by stress and are thought to protect plants against various biotic and abiotic stressors. The production of polyphenols is partly under genetic control and partly determined by environmental conditions (HERMS; MATTSON, 1992). Under natural conditions, plants rarely experience single abiotic factors alone and are much more likely to be exposed to multiple stresses simultaneously (NCUBE; FINNIE; VAN STADEN, 2012). Seasonal climatic changes are associated with a variety of different stress factors in combination, and hence, the response of plants are not always predictable and are highly complex (HOLOPAINEN; GERSHENZON, 2010). Nevertheless, these factors are most commonly investigated individually.

In this study, we detected a close relationship between photosynthesis and total tannin contents and a positive correlation of these parameters with temperature (Tables 1 and 2). The seasonal accumulation of tannins observed in Stryphnodendron adstringens in the rainy season is mainly dependent on carbon skeletons produced through the photosynthetic process, which has often been reported in literature (KORICHEVA et al., 1998; SANTOS et al., 2006; NYBAKKEN; SANDVIK; KLANDER, 2011) and it suggests that the rainy season is the best time in order to obtain the stem barks for medicinal purposes. 
TABLE 2: Pearson's correlation coefficients (r) between PAL activity and the total phenols and tannin contents with gas exchange and water potential characteristics and environmental variables.

TABELA 2: Coeficiente de correlação de Pearson (r) entre a atividade da PAL e os teores de fenóis e taninos totais com as características de trocas gasosas e potencial hídrico e variáveis ambientais.

Correlation of gas exchange values and weather conditions

\begin{tabular}{|c|c|c|}
\hline & Positive Correlation & Negative Correlation \\
\hline PAL activity & ns & $\begin{array}{c}\text { gs }\left(-0.24^{*}\right), \text { A }\left(-0.54^{*}\right), \text { E }\left(-0.36^{*}\right), \text { WUE }\left(-0.42^{*}\right) \text {, PPFD }\left(-0.35^{*}\right) \text {, VPD } \\
\left(-0.49^{*}\right), \text { TMAX }\left(-0.38^{*}\right) \text {, TMED }\left(-0.56^{*}\right) \text {, TMIN }\left(-0.55^{*}\right) \\
\text { RAINF }\left(-0.30^{*}\right)\end{array}$ \\
\hline Total phenols & ns & $\begin{array}{c}\text { E }\left(-0.17^{*}\right), \text { WPmax }\left(0.33^{*}\right), \\
\operatorname{TMED}\left(-0.17^{*}\right), \text { TMIN }\left(-0.17^{*}\right), \operatorname{RAINF}\left(-0.18^{*}\right)\end{array}$ \\
\hline Total tannins & $\begin{array}{l}\text { A }\left(0.28^{*}\right) \text {, WUE }\left(0.35^{*}\right) \text {, VPD }\left(0.34^{*}\right), \operatorname{WPmin}\left(0.28^{*}\right) \text {, } \\
\text { TMAX }\left(0.49^{*}\right), \text { TMED }\left(0.51^{*}\right), \text { TMIN }\left(0.41^{*}\right)\end{array}$ & WPmax (-0.18*) \\
\hline \multicolumn{3}{|c|}{$\begin{array}{l}\text { *Correlation significant by t test }(\mathrm{P}<0.05) \text {; } \mathrm{ns} \text { - correlation non-significant by t test }(\mathrm{P}<0.05) . \mathrm{A}=\text { net photosynthesis; } \\
\mathrm{E}=\text { transpiration rate; gs= stomatal conductance; WUE = water use efficiency; WPmax }=\text { maximum leaf water } \\
\text { potential; WPmin= minimum leaf water potential; } \mathrm{PPFD}=\text { photosynthetic photon flux density; } \mathrm{VPD}=\text { vapor pressure } \\
\text { deficit }(\mathrm{VPD}) \text {; } \mathrm{TMAX}=\text { maximum temperature; TMED= medium temperature; TMIN= minimum temperature; } \\
\text { RAINF= rainfall. }\end{array}$} \\
\hline
\end{tabular}

Heyworth et al. (1998) and Koricheva et al. (1998) described vegetable tannins as carbon-based secondary compounds and noted that their biosynthesis related to growth or differentiation processes in plants is regulated by the availability of environmental resources. According to Zobayed, Affren and Kozai (2005), one of the major environmental factors affecting the physiological processes of plants, especially photosynthesis and growth, is temperature. In this context, increased concentrations of secondary metabolites may also be associated with the partitioning and translocation of carbon for incorporation into carbon-based secondary compounds. Recent biochemical and molecular studies strongly support the idea that the levels of carbon-based secondary compounds are positively linked to the contents of available photosynthates (carbon, C) and negatively linked to growth and nutrient status (nitrogen, N) in plants (NYBAKKEN; SANDVIK; KLANDER, 2011).

\section{CONCLUSION}

This study suggests that seasonal accumulation of tannins in Stryphnodendron adstringens with the highest contents in the rainy season is dependent on carbon skeletons produced in the photosynthetic process. These results encourage additional agronomic and biochemical studies, with the perspective of sustainable use of this species for economic and medicinal purposes.

\section{ACKNOWLEDGMENTS}

This work was supported by the Fundação de Amparo à Pesquisa do Estado de Minas Gerais (FAPEMIG). The authors gratefully acknowledge to Dr. Rupert Barros de Freitas and Joel Donizetti Vilas Boas for assistance in the field.

\section{REFERENCES}

ALBERNAZ, L. C. et al. Investigation of plant extracts in traditional medicine of the Brazilian Cerrado against protozoans and yeasts. Journal of Ethnopharmacology, Melbourne, v. 131, n. 1, p. 116-121, 2010. 
ASSIS, J. S. et al. Effect of high carbon dioxide concentration on PAL activity and phenolic contents in ripening cherimoya fruit. Postharvest Biology and Technology, Sydney, v. 23, n. 1, p. 33-39, 2001.

BARBEHENN, R. V.; CONSTABEL, C. P. Tannins in plant-herbivore interactions. Phytochemistry, Melbourne, v. 72, n. 13, p. 1551-1565, 2011.

BARBEHENN, R. V. et al. Hydrolysable tannins as “quantitative defenses": limited impact against Lymantria dispar caterpillars on hybrid poplar. Journal of Insect Physiology, Melbourne, v. 55, n. 4, p. 297-304, 2009.

BATLLE-BAYER, L.; BATJES, N. H.; BINDRABAN, P. S. Changes in organic carbon stocks upon land use conversion in the Brazilian Cerrado: a review. Agriculture, Ecosystems \& Environment, Sydney, v. 137, n. $1 / 2$, p. $47-58,2010$.

BRASIL. Ministério da Agricultura e Reforma Agrária. Secretaria Nacional de Irrigação. Departamento Nacional de Meteorologia. Normais climatológicas (1961-1990). Brasília: MARA, 1992. 84 p.

BUCCI, S. J. et al. Controls on stand transpiration and soil water utilization along a tree density gradient in a Neotropical savanna. Agricultural and Forest Meteorology, Melbourne, v. 148, n. 6-7, p. 839-849, 2008. COSTA, M. A. et al. Safety evaluation of proanthocyanidin polymer-rich fraction obtained from stem bark of Stryphnodendron adstringens (BARBATIMÃO) for use as a pharmacological agent. Regulatory Toxicology and Pharmacology, Chatswood, v. 58, n. 2, p. 330-335, 2010.

DANTAS, A. A. A.; CARVALHO, L.; FERREIRA, E. Classificação e tendências climáticas em Lavras, MG. Ciência e Agrotecnologia, Lavras, v. 31, n. 6, p. 1862-1866, 2007.

FALCÃO, H. S. et al. Plants of the American continent with antiulcer activity. Phytomedicine, Melbourne, v. 15, n. $1 / 2$, p. 132-146, 2008.

GERM, M. et al. Flavonoid, tannin and hypericin concentrations in the leaves of St. John's wort (Hypericum perforatum L.) are affected by UV-B radiation levels. Food Chemistry, Chatswood, v. 122, n. 3, p. 471-474, 2010.

GIBERT, S. et al. Two phenylalanine ammonia lyase isoforms are involved in the elicitor-induced response of rice to the fungal pathogen Magnaporthe oryzae. Journal of Plant Physiology, Sydney, v. 169, n. 3, p. 249-254, 2012.

GRACE, J. et al. Productivity and carbon fluxes of tropical savannas. Journal of Biogeography, Oxford, v. 33, n. 3, p. 387-400, 2006.

HAGERMAN, A. E. Radial diffusion method for determining tannin in plant extracts. Journal of Chemical Ecology, Syracuse, v. 13, n. 3, p. 437-449, 1987.

HARIDASAN, M. Nutritional adaptations of native plants of the cerrado biome in acid soils. Brazilian Journal of Plant Physiology, Brasília, v. 20, n. 3, p. 183-195, 2008.

HERMS, D. A.; MATTSON, W. J. The dilemma of plants: to grown or defense. The Quarterly Review of Biology, Chicago, v. 67, n. 3, p. 283-335, 1992.

HERNANDES, L. et al. Wound-healing evaluation of ointment from Stryphnodendron adstringens (barbatimão) in rat skin. Brazilian Journal of Pharmaceutical Science, São Paulo, v. 46, n. 3, p. 431-436, 2010.

HEYWORTH, C. J. et al. The effect of elevated CO2 concentration and nutrient supply on carbon-based plant secondary metabolites in Pinus sylvestris L. Oecologia, Oxford, v. 115, n. 3, p. 344-350, 1998.

HOLOPAINEN, J. K.; GERSHENZON, J. Multiple stress factors and the emission of plant VOCs. Trends in Plant Science, Chatswood, v. 15, n. 3, p. 176-184, 2010.

KÖPPEN, W. Climatologia. Fondo de Cultura Economica. Buenos Aires: L.O.L.A, 1948. 478 p.

KORICHEVA, J. et al. Regulation of woody plant secondary metabolism by resource availability: hypothesis testing by means of meta-analysis. Oikos, Oxford, v. 83, n. 2, p. 212-226, 1998.

LILIENFEIN, J. et al. Nutrient storage in soil and biomass of native Brazilian cerrado. Journal of Plant Nutrition and Soil Science, Syracuse, v. 164, n. 5, p. 487-495, 2001.

MEINZER, F. C. et al. Atmospheric and hydraulic limitations on transpiration in Brazilian cerrado woody species. Functional Ecology, Syracuse, v. 13, n. 2, p. 273-282, 1999.

NCUBE, B.; FINNIE, J. F.; VAN STADEN, J. Quality from the field: the impact of environmental factors as quality determinants in medicinal plants. South African Journal of Botany, Sydney, v. 82, p. 11-20, 2012. 
NYBAKKEN, L.; SANDVIK, S. M.; KLANDER, U.D. K. Experimental warming had little effect on carbonbased secondary compounds, carbon and nitrogen in selected alpine plants and lichens. Environmental and Experimental Botany, Melbourne, v. 72, n. 3, p. 368-376, 2011.

OH, M. M.; TRICK, H. N.; RAJASHEKAR, C. B. Secondary metabolism and antioxidants are involved in environmental adaptation and stress tolerance in lettuce. Journal of Plant Physiology, Melbourne, v. 166, n. 2, p. 180-191, 2009.

PASTRANA-BONILLA, E. et al. Phenolic content and antioxidant capacity of Muscadine grapes. Journal of Agricultural and Food Chemistry, Chatswood, v. 51, n. 18, p. 5497-5503, 2003.

SANTOS, S. C. et al. Seasonal variation in the content of tannins in barks of barbatimão species. Brazilian Journal of Pharmacognosy, João Pessoa, v. 6, supl, p. 552-556, 2006.

SCHOLZ, F. G. et al. Biophysical properties and functional significance of stem water storage tissues in neo-tropical savanna trees. Plant, Cell \& Environment, Chicago, v. 30, n. 2, p. 236-248, 2007.

SINGLETON, V. L.; ROSSI, J. A. Colorimetry of total phenolics with phosphomolybdic-phosphotungstic acid reagents. American Journal of Enology and Viticulture, Davis, v. 16, n. 3, p. 144-158, 1965.

SOLECKA, D.; KACPERSKA, A. Phenylpropanoid deficiency affects the course of plant acclimation to cold. Physiologia Plantarum, Chicago, v. 119, n. 2, p. 253-262, 2003.

SREELAKSHMI, Y.; SHARMA, R. Differential regulation of phenylalanine ammonia lyase activity and protein level by light in tomato seedlings. Plant Physiology and Biochemistry, Sydney, v. 46, n. 4, p. 444-451, 2008.

WINKEL-SHIRLEY, B. Flavonoid biosynthesis: a colorful model for genetics, biochemistry, cell biology and biotechnology. Plant Physiology, Melbourne, v. 126, n. 2, p. 485-493, 2001.

ZOBAYED, S. M. A.; AFREEN, F.; KOZAI, T. Temperature stress can alter the photosynthetic efficiency and secondary metabolite concentrations in St. John's Wort. Plant Physiology and Biochemistry, Sydney, v. 43, n. 10-11, p. 977-984, 2005.

ZUCKER, M. Induction of phenylalanine deaminase by light and its relation to chlorogenic acid synthesis in potato tuber tissue. Plant Physiology, Melbourne, v. 40, n. 5, p. 779-784, 1965. 